\title{
Idaho National Laboratory Emergency Readiness Assurance Plan - Fiscal Year 2017
}

September 2017

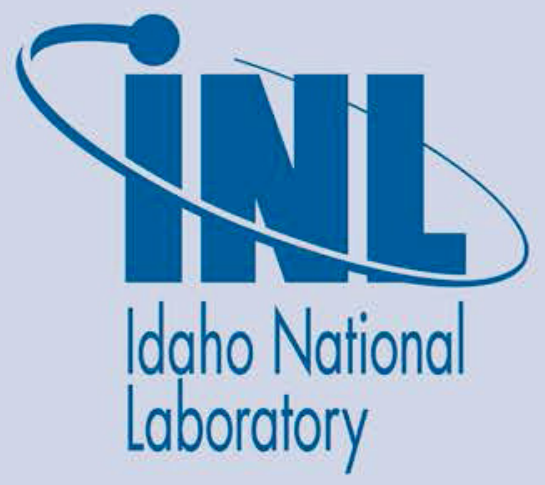

The INL is a U.S. Department of Energy National Laboratory operated by Battelle Energy Alliance 


\section{DISCLAIMER}

This information was prepared as an account of work sponsored by an agency of the U.S. Government. Neither the U.S. Government nor any agency thereof, nor any of their employees, makes any warranty, expressed or implied, or assumes any legal liability or responsibility for the accuracy, completeness, or usefulness, of any information, apparatus, product, or process disclosed, or represents that its use would not infringe privately owned rights. References herein to any specific commercial product, process, or service by trade name, trade mark, manufacturer, or otherwise, does not necessarily constitute or imply its endorsement, recommendation, or favoring by the U.S. Government or any agency thereof. The views and opinions of authors expressed herein do not necessarily state or reflect those of the U.S. Government or any agency thereof. 
INL/EXT-17-43241

Revision 0

\title{
Idaho National Laboratory Emergency Readiness Assurance Plan — Fiscal Year 2017
}

September 2017

Idaho National Laboratory Emergency Management

Idaho Falls, Idaho 83415

\author{
http://www.inl.gov
}

Prepared for the

U.S. Department of Energy

Under DOE Idaho Operations Office

Contract DE-AC07-05ID14517 


\section{ABSTRACT}

Battelle Energy Alliance, LLC, the prime contractor for Idaho National Laboratory (INL), provides this Emergency Readiness Assurance Plan (ERAP) for Fiscal Year 2017 in accordance with DOE O 151.1C, "Comprehensive Emergency Management System." The ERAP documents the readiness of the INL Emergency Management Program using emergency response planning and preparedness activities as the basis. It describes emergency response planning and preparedness activities, and where applicable, summarizes and/or provides supporting information in tabular form for easy access to data. The ERAP also provides budget, personnel, and planning forecasts for Fiscal Year 2018.

Specifically, the ERAP assures the Department of Energy Idaho Operations Office that stated emergency capabilities at INL are sufficient to implement PLN-114, "INL Emergency Plan/RCRA Contingency Plan." 


\section{CONTENTS}

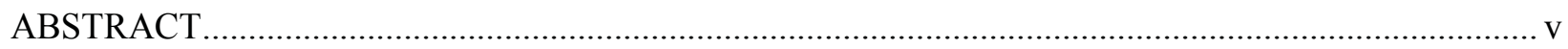

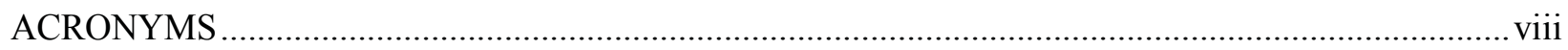

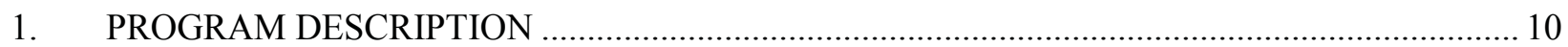

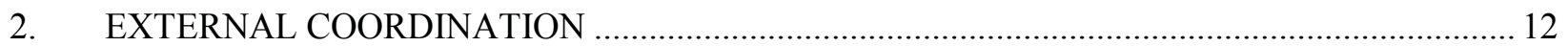

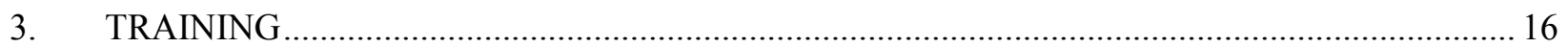

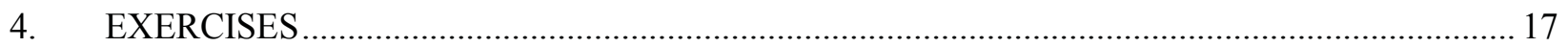

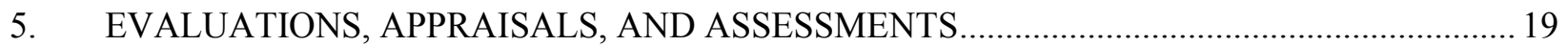

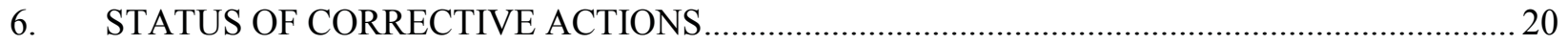

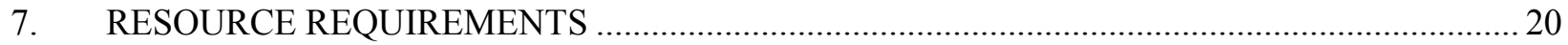

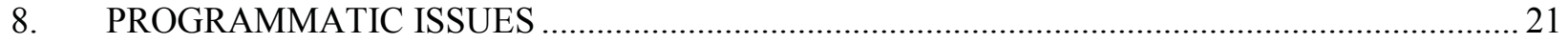

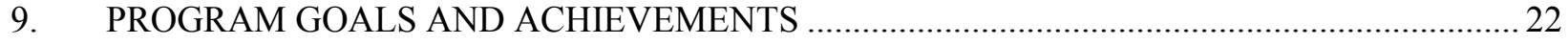

Appendix A DOE O 151.1D Implementation Schedule ......................................................................24

Appendix B Threat and Hazard Identification Risk Assessment (THIRA) ….......................................26

\section{TABLES}

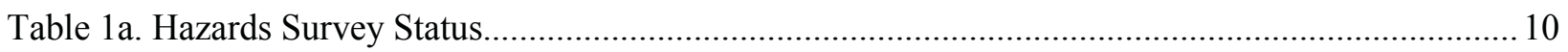

Table 1b. Emergency Management Hazards Assessments Status. ........................................................... 11

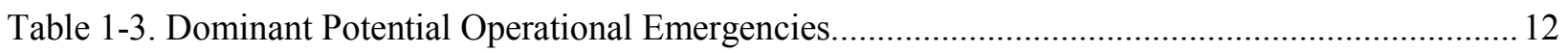

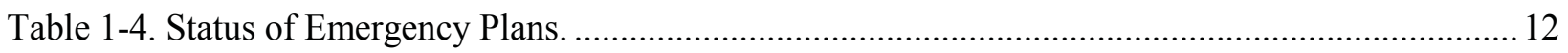

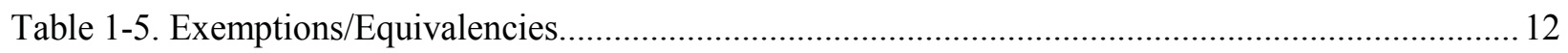

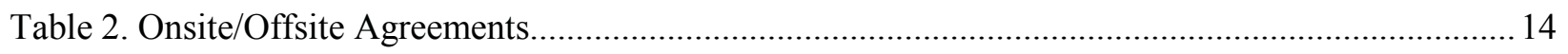

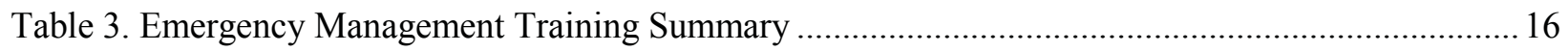

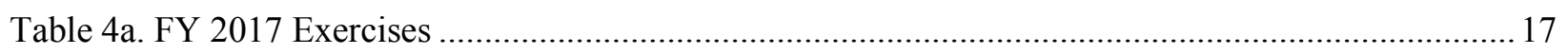

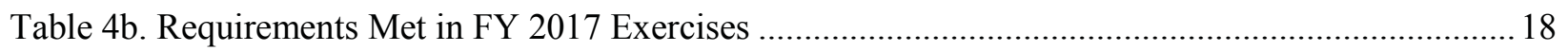

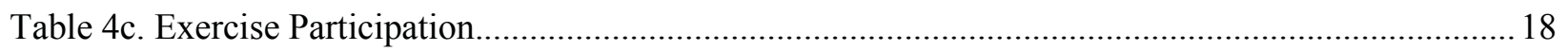

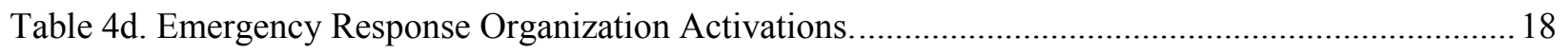

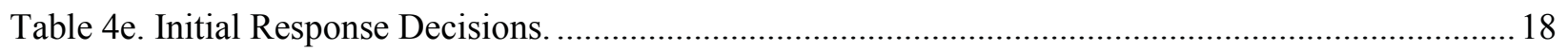

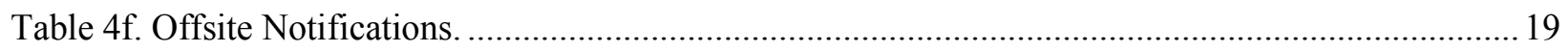

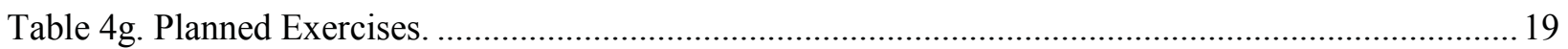




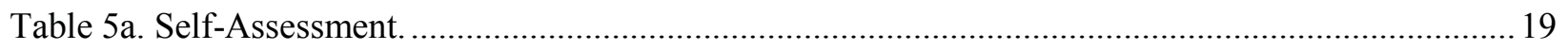

Table 5b. Emergency Management Evaluation, Appraisal, Assessment, and Inspection Schedule...........20

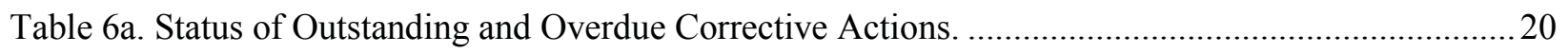

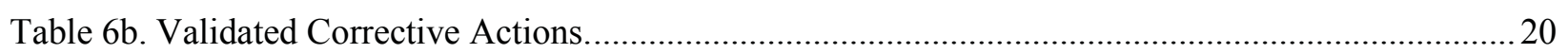

Table 7a. Emergency Management Personnel Full-Time Equivalents.................................................... 20

Table 7b. Emergency Management Operational Budget. ........................................................................... 20

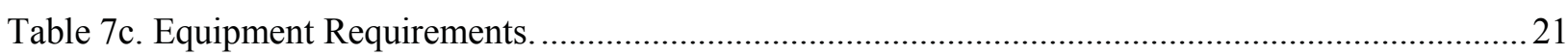

Table 9a. INL EM Program achievements (goals, milestones, objectives, and status) for FY 2017......... 22

Table 9b. INL EM Program projections (goals, milestones) for FY 2018...............................................22 


\section{ACRONYMS}

A alert

ATR Advanced Test Reactor

BEA Battelle Energy Alliance, LLC

CFA Central Facilities Area

CY Calendar Year

CFE Cognizant Field Element

DOE Department of Energy

DOE-ID Department of Energy Idaho Operations Office

EALs emergency action levels

EAM emergency action manager

ECCs Emergency Control Centers

ED emergency director

EM emergency management

EMISIG Emergency Management Issues Special Interest Group

EOC Emergency Operations Center

EPHA emergency planning hazards assessment

EPHS emergency planning hazards survey

ERAP Emergency Readiness Assurance Plan

ERO emergency response organization

FY Fiscal Year

GE general emergency

ICS Incident Command System

INL Idaho National Laboratory

IOEM Office of Emergency Management

JIC joint information center

LOAs Letters of Agreement

MFC Materials and Fuels Complex

MAAs Mutual Aid Agreements

MOAs Memoranda of Agreements

MOUs Memoranda of Understandings

N/A not applicable

NNSA National Nuclear Security Administration

OE operational emergency

REC Research and Education Campus

SAE site area emergency 
SMC Specific Manufacturing Capability

THIRA Threat and Hazard Identification Risk Analysis 


\section{Idaho National Laboratory Emergency Readiness Assurance Plan — Fiscal Year 2017 \\ 1. PROGRAM DESCRIPTION}

Battelle Energy Alliance, LLC (BEA), the prime contractor for Idaho National Laboratory (INL), provides this Emergency Readiness Assurance Plan (ERAP) for Fiscal Year (FY) 2017 in accordance with DOE O 151.1C, "Comprehensive Emergency Management System." The ERAP documents the readiness of the INL Emergency Management Program and assures the Department of Energy (DOE) Idaho Operations Office (DOE-ID) that stated emergency capabilities at INL are sufficient to implement PLN-114, "INL Emergency Plan/RCRA Contingency Plan."

The INL Emergency Management Program is fully matured as a hazardous material program as defined by DOE O $151.1 \mathrm{C}$ and continues to be an effective response program. DOE O 151.1C was added to the Prime Contract between DOE-ID and BEA, Contract No. DE-AC07-05ID14517, "Management and Operation of the Idaho National Laboratory," in July 2006. All programmatic milestones were met during FY 2017. The National Incident Management System Implementation Plan is fully implemented and being maintained in compliance with DOE O 151.1C.

INL consists of the INL Site, which is an 890-square-mile desert area 45 miles west of Idaho Falls, Idaho, and multiple facilities at the Research and Education Campus (REC) in Idaho Falls. The ERAP covers only those INL facilities operated by BEA. It does not cover facilities operated by Fluor Idaho, LLC, or the Naval Reactors Facility operated by the DOE Pittsburgh Naval Reactors Office.

Based on the results of INL emergency planning hazards surveys (EPHSs) and emergency planning hazards assessments (EPHAs), INL has established an operational emergency (OE) hazardous material program as defined by DOE O $151.1 \mathrm{C}$.

INL Emergency Management develops and maintains EPHS/EPHA documents for INL facilities operated by BEA. All INL EPHSs and EPHAs are DOE O 151.1C compliant. The review cycles and DOE O 151.1C compliance status for all EPHSs and EPHAs are indicated in Table 1a and Table 1b, respectively. There are no overdue EPHS/EPHAs.

Table 1a. Hazards Survey Status.

\begin{tabular}{|c|c|c|c|c|c|}
\hline \multicolumn{5}{|c|}{ Total Hazard Surveys for Site } & 5 \\
\hline \multicolumn{5}{|c|}{ Total Hazards Surveys overdue for completion/revision } & 0 \\
\hline Building/Facility & $\begin{array}{l}\text { Planned } \\
\text { Completion } \\
\text { Date }\end{array}$ & $\begin{array}{c}\text { Actual } \\
\text { Completion } \\
\text { Date }\end{array}$ & $\begin{array}{c}\text { EPHA } \\
\text { Required }\end{array}$ & $\begin{array}{c}\text { Update (when } \\
\text { hazards change or } 3 \\
\text { years) }\end{array}$ & $\begin{array}{c}\text { Hazards } \\
\text { Survey } \\
\text { Posted on } \\
\text { SharePoint } \\
\text { Site }\end{array}$ \\
\hline ATR Complex & $10 / 21 / 14$ & $10 / 21 / 14$ & Yes & $10 / 21 / 17$ & No \\
\hline $\begin{array}{l}\text { CFA (includes } \\
\text { transportation }\end{array}$ & $07 / 17 / 15$ & $07 / 17 / 15$ & Yes & $07 / 17 / 18$ & No \\
\hline $\mathrm{MFC}$ & 07/09/17 & $06 / 26 / 17$ & Yes & $06 / 26 / 20$ & No \\
\hline REC & $05 / 28 / 15$ & $05 / 28 / 15$ & Yes & $05 / 28 / 18$ & No \\
\hline
\end{tabular}


Table 1a. (continued).

\begin{tabular}{|l|c|c|c|c|c|}
\hline \multicolumn{1}{|c|}{ SMC } & $10 / 16 / 15$ & $10 / 16 / 15$ & Yes & $10 / 16 / 18$ & No \\
\hline 1 & ATR = Advanced Test Reactor & \multicolumn{4}{l|}{ MFC = Materials and Fuels Complex } \\
REC = Research and Education Campus & \multicolumn{3}{l}{ SMC = Specific Manufacturing Capability } \\
CFA = Central Facilities Area
\end{tabular}

The generic types of OEs that have been identified that could affect the INL are:

- $\quad$ Fires that cause, or could potentially cause, serious health and safety impacts to workers or members of the public

- An unplanned explosion that results in, or is suspected to result in, personnel injury

- The discovery of radioactive contamination from past DOE/National Nuclear Security Administration (NNSA) operations that may cause uncontrolled personnel exposures exceeding protective action criteria

- The release of a nonradioactive chemical where the incident commander recommends a facility evacuation or sheltering, or that requires a time-urgent response by specialist personnel

- Any natural phenomenon that may impact health and safety of personnel

- A loss of commercial power and failure of emergency generators and/or backup power supplies that could compromise personnel health and safety due to either release of hazardous material or temperature extremes

- Any unplanned criticality

- Any event that damages or compromises barriers around hazardous materials, structures, or equipment that are intended to protect the health and safety of personnel and results in suspected or confirmed personnel injury or health or degradation of health and safety, or requires personnel in nearby buildings to shelter or evacuate

- An external event involving an offsite hazardous material not associated with DOE operations where the incident commander recommends a facility evacuation or sheltering, or that requires time-urgent response by specialist personnel not normally assigned to the affected area.

Table 1b. Emergency Management Hazards Assessments Status.

\begin{tabular}{|c|c|c|c|c|}
\hline Total EPHAs for $\mathrm{S}$ & & & & 5 \\
\hline Total EPHAs over & ue for completion/revi & & & 0 \\
\hline Building/Facility & $\begin{array}{c}\text { Planned Completion } \\
\text { Date }\end{array}$ & Completion Date & $\begin{array}{c}\text { Update (every } 3 \\
\text { years or when } \\
\text { hazards change) }\end{array}$ & $\begin{array}{c}\text { EPHA Posted } \\
\text { on } \\
\text { SharePoint } \\
\text { Site }\end{array}$ \\
\hline ATR Complex & $03 / 10 / 16$ & $02 / 28 / 16$ & $03 / 11 / 19$ & No \\
\hline $\begin{array}{l}\text { CFA (includes } \\
\text { transportation) }\end{array}$ & $07 / 31 / 15$ & $07 / 31 / 15$ & $07 / 31 / 18$ & No \\
\hline MFC & $11 / 25 / 15$ & $11 / 25 / 15$ & $11 / 25 / 18$ & No \\
\hline REC & $10 / 13 / 15$ & $10 / 13 / 15$ & $10 / 13 / 18$ & No \\
\hline SMC & $10 / 16 / 15$ & $10 / 16 / 15$ & $10 / 16 / 18$ & No \\
\hline
\end{tabular}

As indicated in the EPHSs, the OEs that could affect INL facilities are the result of radiological and 
hazardous material releases. The dominant hazards at INL in terms of the most severe consequences (i.e., general emergency [GE], site area emergency [SAE], or alert [A]; biological release OEs) from potential OEs are indicated in Table 1-3. There are no biological select agents present at INL.

Table 1-3. Dominant Potential Operational Emergencies.

\begin{tabular}{|c|c|c|c|c|}
\hline \multirow[b]{2}{*}{ Facility } & \multicolumn{3}{|c|}{ Emergency Class } & \multirow{2}{*}{$\begin{array}{l}\text { Radionuclide/Chemical/ } \\
\text { Biological Agent/Toxin-Material }\end{array}$} \\
\hline & GE & SAE & A & \\
\hline ATC Complex & $\mathrm{X}$ & $\mathrm{X}$ & $\mathrm{X}$ & $\begin{array}{l}\text { Chemical - Chlorine, Hydrofluoric acid } \\
\text { Radionuclide - Various }\end{array}$ \\
\hline $\begin{array}{l}\text { CFA (includes } \\
\text { transportation }\end{array}$ & $X$ & $X$ & $\mathrm{X}$ & $\begin{array}{l}\text { Chemical - Cyclohexelamine, Nitric acid } \\
\text { Radionuclide - Various }\end{array}$ \\
\hline $\mathrm{MFC}$ & $\mathrm{X}$ & $\mathrm{X}$ & $\mathrm{X}$ & $\begin{array}{l}\text { Chemical - Sodium hydroxide } \\
\text { Radionuclide - Various }\end{array}$ \\
\hline REC & & & & OE Unclassified \\
\hline $\mathrm{SMC}$ & & $\mathrm{X}$ & $\mathrm{X}$ & $\begin{array}{l}\text { Chemical - Cyclohexelamine, Depleted Uranium } \\
\text { Radionuclide - Various }\end{array}$ \\
\hline
\end{tabular}

PLN- 114 is fully mature and in a maintenance mode of operation. Annual review of PLN- 114 was completed on schedule. Table 1-4 provides the status of the BEA emergency plan.

Table 1-4. Status of Emergency Plans.

\begin{tabular}{|c|c|c|c|c|c|c|c|}
\hline \multirow{2}{*}{$\begin{array}{l}\text { Plan or } \\
\text { Procedure } \\
\text { Reference } \\
\text { Number }\end{array}$} & \multirow[b]{2}{*}{ Title } & \multirow[b]{2}{*}{$\begin{array}{l}\text { Date of } \\
\text { Issue }\end{array}$} & \multirow[b]{2}{*}{$\begin{array}{l}\text { Date Due } \\
\text { Reviewed }\end{array}$} & \multicolumn{3}{|c|}{ Status } & \multirow[b]{2}{*}{$\begin{array}{c}\text { Posted on } \\
\text { SharePoint } \\
\text { Site }\end{array}$} \\
\hline & & & & 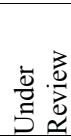 & $\begin{array}{l}\text { D } \\
\text { o. } \\
\text { : }\end{array}$ & 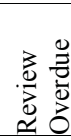 & \\
\hline PLN-114 & $\begin{array}{l}\text { INL Emergency Plan/RCRA } \\
\text { Contingency Plan }\end{array}$ & $05 / 25 / 16$ & $05 / 25 / 18$ & & $\mathrm{X}$ & & No \\
\hline
\end{tabular}

As specified in Table 1-5, BEA has no exemptions with DOE O 151.1C, Attachment 2, "Contractor Requirements Document."

Table 1-5. Exemptions/Equivalencies

\begin{tabular}{|c|c|c|c|c|}
\hline Exemption/Waiver & Reason & $\begin{array}{c}\text { Approver's } \\
\text { Date of } \\
\text { Submission }\end{array}$ & $\begin{array}{c}\text { Name/Title and } \\
\text { Approval Date }\end{array}$ & Duration \\
\hline No exemptions requested & N/A & N/A & N/A & N/A \\
\hline
\end{tabular}

\section{EXTERNAL COORDINATION}

The INL Offsite Emergency Planning Program, established by the DOE-ID Emergency Management (EM) organization, is maintained by BEA, managed by INL EM, and administered by the INL EM public liaison. Federal, tribal, state, and local agencies participate with the INL EM public liaison in the INL Offsite Emergency Planning Program, which, through agreements, defines cooperative emergency policies and procedures. Formal documentation of participants' defined roles is recorded in federal interagency agreements, internal DOE agreements or directives, legislation and federal regulations, state regulations, and state and local emergency plans. Mutual aid agreements are documented in memoranda of understanding, memoranda of agreement, or letters of agreement. All 
affected offsite agencies cited in this section have entered into mutual aid agreements with DOE-ID.

BEA, through the INL Offsite Emergency Planning Program, familiarizes local fire departments, and emergency response teams with the layout of the INL desert site and the REC, properties of hazardous material handled at the facilities, associated hazards and locations where personnel would normally work, entrances to roads inside the facilities, and possible evacuation routes. To accomplish this, INL's EM offers opportunities for offsite agencies to participate in onsite and offsite drills and exercises or conducts site walk-throughs and orientation sessions, if requested.

The INL EM public liaison also interfaces with federal, state, local, and tribal offsite agencies and/or jurisdictions by:

- Meeting with federal, state, local, and tribal offsite agency and/or jurisdiction representatives, as needed, and ensuring that areas of concern and revisions to emergency response procedures are discussed, as appropriate

- Meeting with various state agencies, as needed, to discuss topics such as development/revision of emergency plans and procedures, emergency action levels (EALs), and agreements, response capabilities, areas of expertise, assignment of responsibility, and other concerns

- Attending scheduled meetings of county and regional local emergency planning committees to discuss development/revisions of emergency plans and procedures and EALs, response capabilities, areas of expertise, assignment of responsibility, and other concerns.

The INL EM public liaison can also arrange for offsite agencies and/or jurisdictions, including hospitals, to receive a copy of the INL Emergency Plan/Resource Conservation and Recovery Act Contingency Plan to provide information on INL and REC emergencies during disasters.

If requested, BEA conducts orientation sessions for hospital personnel to familiarize them with the properties of hazardous material handled at the facilities and the types of injuries or illnesses that might occur from fires, explosions, or releases of hazardous material. If requested, the BEA fire marshal provides a chemical inventory of hazardous chemicals and associated material safety data sheets to the Office of Emergency Management (IOEM) and other agencies.

Table 2 lists current Memoranda of Understandings (MOUs), Memoranda of Agreements (MOAs), Mutual Aid Agreements (MAAs), and/or Letters of Agreement (LOAs) directly related to INL EM, Emergency Response, and Law Enforcement. 
Table 2. Onsite/Offsite Agreements

\begin{tabular}{|c|c|c|c|c|}
\hline MOU/MOA/MAA/LOA & $\begin{array}{c}\text { Date of } \\
\text { Agreement }\end{array}$ & Expiration & $\begin{array}{l}\text { Date of } \\
\text { Review }\end{array}$ & $\begin{array}{c}\text { Date of } \\
\text { Renewal }\end{array}$ \\
\hline $\begin{array}{l}\text { Memorandum of Understanding Between the } \\
\text { State of Idaho and U.S. Department of Energy } \\
\text { Idaho Operations Office - Radiological } \\
\text { Assistance Response for DOE and/or non-DOE } \\
\text { Incidents In Public Access Areas }\end{array}$ & 01/07/94 & $\begin{array}{l}\text { Review at } \\
\text { request of } \\
\text { either party }\end{array}$ & & \\
\hline $\begin{array}{l}\text { Memorandum of Understanding Between U.S. } \\
\text { Department of Energy Idaho Operation Office } \\
\text { and The State of Idaho For Emergency } \\
\text { Preparedness }\end{array}$ & $10 / 20 / 15$ & & $10 / 20$ & \\
\hline $\begin{array}{l}\text { Memorandum of Understanding By and } \\
\text { Between United States Department of Energy } \\
\text { Idaho Operations Office and Bingham County } \\
\text { Sheriff's Office }\end{array}$ & $03 / 25 / 15$ & & $10 / 20$ & \\
\hline $\begin{array}{l}\text { Memorandum of Understanding By and } \\
\text { Between United States Department of Energy } \\
\text { Idaho Operations Office and Bonneville } \\
\text { County Sheriff's Office }\end{array}$ & $10 / 02 / 14$ & & $10 / 19$ & \\
\hline $\begin{array}{l}\text { Memorandum of Understanding By and } \\
\text { Between United States Department of Energy } \\
\text { Idaho Operations Office and Bonneville } \\
\text { County Sheriff's Office (Bomb dog agreement) }\end{array}$ & $10 / 02 / 14$ & $\begin{array}{l}\text { Through } \\
\text { the useful } \\
\text { life of the } \\
\text { canine }\end{array}$ & & \\
\hline $\begin{array}{l}\text { Memorandum of Understanding By and } \\
\text { Between United States Department of Energy } \\
\text { Idaho Operations Office and Butte County } \\
\text { Sheriff's Office }\end{array}$ & $03 / 09 / 15$ & & $03 / 20$ & \\
\hline $\begin{array}{l}\text { Memorandum of Understanding By and } \\
\text { Between United States Department of Energy } \\
\text { Idaho Operations Office and Clark County } \\
\text { Sheriff's Office }\end{array}$ & $07 / 30 / 14$ & & $07 / 19$ & \\
\hline $\begin{array}{l}\text { Memorandum of Understanding By and } \\
\text { Between United States Department of Energy } \\
\text { Idaho Operations Office and the Jefferson } \\
\text { County Sheriff's Office }\end{array}$ & $12 / 02 / 14$ & & $12 / 19$ & \\
\hline $\begin{array}{l}\text { Memorandum of Understanding By and } \\
\text { Between United States Department of Energy } \\
\text { Idaho Operations Office and City of Idaho } \\
\text { Falls, Police Department (Bomb dog } \\
\text { agreement) }\end{array}$ & 08/19/08 & $\begin{array}{l}\text { Through } \\
\text { the useful } \\
\text { life of the } \\
\text { canine }\end{array}$ & & \\
\hline $\begin{array}{l}\text { Memorandum made this } 4^{\text {th }} \text { day of September, } \\
2007 \text { between United States Department of } \\
\text { Energy Idaho Operations Office (DOE-ID) and } \\
\text { the City of Idaho Falls, Idaho Police } \\
\text { Department (IFPD) }\end{array}$ & $09 / 05 / 07$ & $\begin{array}{c}\text { Not } \\
\text { identified }\end{array}$ & $\begin{array}{c}\text { None } \\
\text { specified }\end{array}$ & \\
\hline
\end{tabular}


Table 2. (continued).

\begin{tabular}{|c|c|c|c|c|}
\hline MOU/MOA/MAA/LOA & $\begin{array}{c}\text { Date of } \\
\text { Agreement }\end{array}$ & Expiration & $\begin{array}{l}\text { Date of } \\
\text { Review }\end{array}$ & $\begin{array}{c}\text { Date of } \\
\text { Renewal }\end{array}$ \\
\hline $\begin{array}{l}\text { Memorandum of Understanding By and } \\
\text { Between United States Department of Energy } \\
\text { Idaho Operations Office and Bingham County } \\
\text { Emergency Management Services }\end{array}$ & $07 / 30 / 14$ & & $07 / 19$ & \\
\hline $\begin{array}{l}\text { Memorandum of Understanding By and } \\
\text { Between United States Department of Energy } \\
\text { Idaho Operations Office and Bonneville } \\
\text { County Emergency Management Services }\end{array}$ & $01 / 15 / 15$ & & $01 / 19$ & \\
\hline $\begin{array}{l}\text { Memorandum of Understanding By and } \\
\text { Between United States Department of Energy } \\
\text { Idaho Operations Office and Butte County } \\
\text { Emergency Services }\end{array}$ & $07 / 25 / 11$ & & $07 / 16$ & \\
\hline $\begin{array}{l}\text { Memorandum of Understanding By and } \\
\text { Between United States Department of Energy } \\
\text { Idaho Operations Office and Clark County } \\
\text { Civil Defense }\end{array}$ & $01 / 21 / 15$ & & $01 / 19$ & \\
\hline $\begin{array}{l}\text { Memorandum of Understanding By and } \\
\text { Between United States Department of Energy } \\
\text { Idaho Operations Office and Jefferson County } \\
\text { Emergency Management }\end{array}$ & $01 / 26 / 15$ & & $10 / 20$ & \\
\hline $\begin{array}{l}\text { Memorandum of Understanding By and } \\
\text { Between United States Department of Energy } \\
\text { Idaho Operations Office and Portneuf Medical } \\
\text { Center }\end{array}$ & $10 / 27 / 09$ & & $10 / 14$ & \\
\hline $\begin{array}{l}\text { Memorandum of Understanding By and } \\
\text { Between United States Department of Energy } \\
\text { Idaho Operations Office and Eastern Idaho } \\
\text { Regional Medical Center }\end{array}$ & $05 / 16 / 12$ & & $05 / 21$ & \\
\hline $\begin{array}{l}\text { Memorandum of Understanding By and } \\
\text { Between United States Department of Energy } \\
\text { Idaho Operations Office and Bingham } \\
\text { Memorial Hospital }\end{array}$ & $01 / 12 / 16$ & & $12 / 21$ & \\
\hline $\begin{array}{l}\text { Agreement-In-Principle Between the } \\
\text { Shoshone-Bannock Tribes and The United } \\
\text { States Department of Energy }\end{array}$ & $12 / 18 / 12$ & & $12 / 17$ & \\
\hline $\begin{array}{l}\text { Interagency Agreement Between Bureau of } \\
\text { Land Management and INL Fire Department }\end{array}$ & $06 / 20 / 13$ & & $5 / 18$ & \\
\hline $\begin{array}{l}\text { Annual Operating Plan for Mutual Fire Aid } \\
2017 \text { Between Department of Energy Idaho } \\
\text { Operations Office, Idaho National Laboratory } \\
\text { and Idaho Falls District Bureau of Land } \\
\text { Management }\end{array}$ & $06 / 26 / 17$ & & $5 / 18$ & \\
\hline $\begin{array}{l}\text { Memorandum of Understanding By and } \\
\text { Between United States Department of Energy } \\
\text { Idaho Operations Office and The Idaho } \\
\text { Transportation Department }\end{array}$ & $12 / 05 / 12$ & & $12 / 17$ & \\
\hline
\end{tabular}


Table 2. (continued).

\begin{tabular}{|c|c|c|c|c|}
\hline MOU/MOA/MAA/LOA & $\begin{array}{c}\text { Date of } \\
\text { Agreement }\end{array}$ & Expiration & $\begin{array}{l}\text { Date of } \\
\text { Review }\end{array}$ & $\begin{array}{c}\text { Date of } \\
\text { Renewal }\end{array}$ \\
\hline $\begin{array}{l}\text { Environmental Oversight and Monitoring } \\
\text { Agreement (Agreement in Principle) Between } \\
\text { the United States Department of Energy and } \\
\text { The State of Idaho }\end{array}$ & $08 / 31 / 15$ & & $8 / 20$ & \\
\hline $\begin{array}{l}\text { Southeastern Idaho Reciprocal Assistance } \\
\text { Agreement and Operations Plan between City } \\
\text { of American Falls Fire Department, Ammon } \\
\text { Fire Department, Arco Fire Department, } \\
\text { Central Fire District, Chubbuck Fire } \\
\text { Department, U. S. Department of Energy Idaho } \\
\text { Operations Office, Firth Fire District, Fort Hall } \\
\text { Fire District, Idaho National Laboratory Fire } \\
\text { Department, Lost River Fire District, Madison } \\
\text { Fire Department, Pocatello Fire Department, } \\
\text { Shelley Fire District, South Custer Fire } \\
\text { District, Swan Valley Fire Department, Teton } \\
\text { County Fire Department, Ucon Fire } \\
\text { Department }\end{array}$ & $07 / 26 / 17$ & & $5 / 22$ & \\
\hline $\begin{array}{l}\text { Memorandum of Understanding By and } \\
\text { Between United States Department of Energy } \\
\text { Idaho Operations Office and City of Idaho } \\
\text { Falls Fire Department - Reciprocal Fire } \\
\text { Fighting Assistance Agreement }\end{array}$ & $02 / 23 / 17$ & & $2 / 22$ & \\
\hline $\begin{array}{l}\text { Memorandum of Agreement Between the } \\
\text { Naval Reactors Laboratory Field Office and the } \\
\text { Idaho Operations Office }\end{array}$ & $11 / 7 / 12$ & & $\begin{array}{c}\text { None } \\
\text { specified }\end{array}$ & \\
\hline
\end{tabular}

\section{TRAINING}

Table 3 provides the total number and percent of emergency response organization (ERO) members trained as a team in FY 2017.

Table 3. Emergency Management Training Summary

\begin{tabular}{|c|c|c|c|}
\hline $\begin{array}{c}\text { Functional Area (i.e., } \\
\text { Incident Command, EOC, } \\
\text { ECC, JIC, etc.) }\end{array}$ & $\begin{array}{c}\text { Type of Personnel } \\
\text { (EOC, Monitoring Teams, Fire, } \\
\text { Medical, etc.) }\end{array}$ & $\begin{array}{c}\text { Total Number } \\
\text { Requiring } \\
\text { Training }\end{array}$ & $\begin{array}{c}\text { Percent } \\
\text { Trained }\end{array}$ \\
\hline JIC & Contractor personnel & 29 & $100 \%$ \\
\hline EOC & Contractor personnel & 76 & $100 \%$ \\
\hline ATR Complex ECC & Contractor personnel & 52 & $100 \%$ \\
\hline CFA ECC & Contractor personnel & 60 & $100 \%$ \\
\hline MFC ECC & Contractor personnel & 44 & $100 \%$ \\
\hline SMC ECC & Contractor personnel & 23 & $100 \%$ \\
\hline
\end{tabular}




\section{EXERCISES}

On November 9, 2016, a successful evaluated exercise was conducted at INL. The participating EROs were activated and responded to their duty station in a timely and effective manner. They utilized applicable procedures and checklists to efficiently respond to and mitigate the event. The emergency control centers (ECCs), emergency operations center (EOC), and joint information center (JIC) were declared operational when staffing levels were met. Each emergency action manager (EAM) and emergency director (ED) correctly identified applicable EALs and declared an OE within the time requirements. Offsite notifications were completed within the required time limits. The ED recognized the event as a multi-facility event and assumed responsibility for categorization/ classification, notifications, and protective actions/protective action recommendations. As event conditions changed, the classification was effectively upgraded as new EALs were met. Good communications were demonstrated within and in between each of the activated ECCs, EOC control cells, DOE-ID, and Idaho State oversite representative.

Protective actions and protective action recommendations were determined and implemented at ATR Complex. This led to a total evacuation of the ATR Complex. Accountability was completed and personnel successfully loaded onto the evacuation buses. Pro Force personnel responded and established access control to the ATR facility.

Facility monitoring teams and site monitoring teams were deployed and monitoring data relayed to their respective coordinators to be utilized in response actions and consequence assessment activities.

Throughout this exercise, ERO personnel were very proactive, thinking ahead, and demonstrating effective communication techniques. Effective command and control was successfully demonstrated during the exercise, which included effectively coordinating response actions between facilities.

During the drill, 12 of the 16 standardized INL objectives were evaluated using the appropriate demonstration criteria. All 12 objectives were rated satisfactory or satisfactory with improvement needed.

Table 4a. FY 2017 Exercises

\begin{tabular}{|c|c|c|c|c|c|c|}
\hline \multicolumn{6}{|c|}{ Total Site Exercises and Drills } & \multirow{2}{*}{$\begin{array}{c}6 \\
\\
\text { External } \\
\text { Assessment }\end{array}$} \\
\hline $\begin{array}{c}\text { Exercise } \\
\text { Date }\end{array}$ & $\begin{array}{c}\text { THIRA } \\
\text { Category }\end{array}$ & $\begin{array}{l}\text { Type of } \\
\text { Event and/or } \\
\text { Hazard to be } \\
\text { Simulated }\end{array}$ & $\begin{array}{c}\text { Impacted } \\
\text { Facility }\end{array}$ & $\begin{array}{c}\text { HSEEP } \\
\text { Type }\end{array}$ & $\begin{array}{c}\text { Date of } \\
\text { AAR }\end{array}$ & \\
\hline $10 / 12 / 16$ & N/A & $\begin{array}{l}\text { Multiple } \\
\text { (Wildland } \\
\text { Fire, Helo } \\
\text { crash, } \\
\text { Hazmat, } \\
\text { Injuries) }\end{array}$ & SMC & $\begin{array}{c}\text { Evaluated } \\
\text { Drill }\end{array}$ & $11 / 01 / 17$ & No \\
\hline $11 / 09 / 16$ & N/A & $\begin{array}{l}\text { Earthquake/ } \\
\text { Canal Drain }\end{array}$ & $\begin{array}{c}\text { ATR } \\
\text { Complex }\end{array}$ & $\begin{array}{l}\text { Full Scale } \\
\text { Exercise }\end{array}$ & $12 / 15 / 16$ & No \\
\hline $05 / 23 / 17$ & N/A & $\begin{array}{c}\text { Loss of } \\
\text { Power / } \\
\text { Radiological } \\
\text { Release }\end{array}$ & MFC & $\begin{array}{c}\text { Evaluated } \\
\text { Drill }\end{array}$ & $06 / 27 / 17$ & No \\
\hline
\end{tabular}




\begin{tabular}{|c|c|c|c|c|c|c|}
\hline $06 / 27 / 17$ & N/A & $\begin{array}{c}\text { Natural } \\
\text { Phenomena } \\
\text { with Injuries }\end{array}$ & CFA & $\begin{array}{c}\text { Evaluated } \\
\text { Drill }\end{array}$ & $8 / / 17$ & No \\
\hline $09 / 20 / 17$ & N/A & $\begin{array}{c}\text { Explosion } \\
\text { with Hazmat }\end{array}$ & SMC & $\begin{array}{c}\text { Full Scale } \\
\text { Exercise }\end{array}$ & None & No \\
\hline $05 / 23 / 18$ & N/A & $\begin{array}{c}\text { Natural } \\
\text { Phenomena } \\
\text { with Rad } \\
\text { Release }\end{array}$ & MFC & $\begin{array}{c}\text { Full Scale } \\
\text { Exercise }\end{array}$ & None & No \\
\hline
\end{tabular}

Table $4 \mathrm{~b}$ indicates if the following requirements have been met.

Table 4b. Requirements Met in FY 2017 Exercises

\begin{tabular}{|l|c|}
\hline \multicolumn{1}{|c|}{ Requirement } & Yes/No \\
\hline Severe event scenario within past five years & Yes \\
\hline All program elements tested within past five years & Yes \\
\hline Scenarios rotated among hazardous material facilities within 5 years & Yes \\
\hline Offsite participation requested within past 3 years & Yes \\
\hline Radiological response asset participation requested within past 3 years. & Yes \\
\hline
\end{tabular}

Table $4 \mathrm{c}$ shows the percentage of the categories of ERO personnel that participated in the FY 2017 evaluated drills, exercise, and actual events.

Table 4c. Exercise Participation.

\begin{tabular}{|c|c|c|c|}
\hline Category & Drill & Exercise & Actual Event \\
\hline Senior Contractors & $100 \%$ & $100 \%$ & N/A \\
\hline Contractors & $100 \%$ & $100 \%$ & N/A \\
\hline
\end{tabular}

Table $4 \mathrm{~d}$ lists the total activations of the ERO for OEs (actual and evaluated drills/exercises), as well as the total number of activations that did not meet the time goals for activation and achieving minimum staffing (based on the site's implemented emergency plans/procedures).

Table 4d. Emergency Response Organization Activations.

\begin{tabular}{|l|l|}
\hline Total number of ERO Activations & 4 \\
\hline Total number of ERO activations not within time standard & 0 \\
\hline
\end{tabular}

Table 4e lists the total number of OEs (actual and evaluated drills/exercises) requiring a prompt initial response decision (i.e., event categorization/classification) and the total number of prompt initial response decisions that did not meet the time goals required by DOE O 151.1C.

Table 4e. Initial Response Decisions.

\begin{tabular}{|l|l|}
\hline Total number of prompt initial response decisions & 4 \\
\hline Total number of prompt initial response decisions not within time standard & 0 \\
\hline
\end{tabular}


Table $4 \mathrm{f}$ lists the total number of required notifications of OEs (actual and evaluated drills/exercises) to offsite authorities and the total number of notifications that did not meet the time goals required by DOE O 151.1C.

Table 4f. Offsite Notifications.

\begin{tabular}{|l|l|}
\hline Total number of prompt initial response decisions & 4 \\
\hline Total number of prompt initial response decisions not within time standard & 1 \\
\hline
\end{tabular}

The BEA exercises planned for FY 2018 are listed in Table 4g.

Table 4g. Planned Exercises.

\begin{tabular}{|c|c|c|c|c|c|}
\hline Total Site Exercises and Drills & \multicolumn{2}{|l|}{} & 4 \\
\hline $\begin{array}{c}\text { Projected/ } \\
\text { Scheduled Date } \\
(\mathrm{MM} / \mathrm{DD} / \mathrm{YY})\end{array}$ & $\begin{array}{c}\text { Type of } \\
\text { THIRA } \\
\text { Category }\end{array}$ & $\begin{array}{c}\text { Event and/or } \\
\text { Hazard to be } \\
\text { Simulated }\end{array}$ & $\begin{array}{c}\text { Impacted } \\
\text { Facility }\end{array}$ & HSEEP Type & $\begin{array}{c}\text { HQs Support } \\
\text { Desired }\end{array}$ \\
\hline $10 / 24 / 17$ & NA & Rad Release & $\begin{array}{c}\text { ATR } \\
\text { Complex }\end{array}$ & Evaluated Drill & None \\
\hline $05 / 23 / 18$ & NA & $\begin{array}{c}\text { Natural } \\
\text { Phenomena } \\
\text { with Rad } \\
\text { Release }\end{array}$ & MFC & Full Scale Exercise & None \\
\hline $07 / 18$ & NA & Unknown & CFA & Evaluated Drill & None \\
\hline $09 / 18$ & NA & Unknown & SMC & Evaluated Drill & None \\
\hline
\end{tabular}

\section{EVALUATIONS, APPRAISALS, AND ASSESSMENTS}

An EM assessment was conducted in FY 2017. The assessment team determined the overall performance rating of the INL EM Program is "effective." The INL EM Program is mature and successful, demonstrating improvement by implementation of identified opportunities for improvement and implementation of DOE complex-wide lessons learned and compliance issues. The program is documented, compliant, and understood. It generally meets expectations and has minor issues, but no violations of DOE O $151.1 \mathrm{C}$ or other requirements.

Based on assessment results, the assessment team identified 5 findings and 11 opportunities for improvement. These issues do not impact the overall effectiveness of the INL EM Program and do not impact safety, reliability, or regulatory commitment. Issues are documented in the INL LabWay tracking system.

Table 5a lists the total number of planned program element self-assessments and the total number of overdue internal program element self-assessments.

Table 5a. Self-Assessment.

\begin{tabular}{|l|l|}
\hline Total number of planned program element self-assessments & 1 \\
\hline Total number of overdue program element self-assessments & 0 \\
\hline
\end{tabular}


Scheduled evaluations, assessments, and self-assessments for FY 2018 are identified in Table 5b.

Table 5b. Emergency Management Evaluation, Appraisal, Assessment, and Inspection Schedule.

\begin{tabular}{|c|c|c|c|}
\hline FY/Quarter & Activity & Conducting Organization & $\begin{array}{c}\text { Program Element(s) } \\
\text { Assessed }\end{array}$ \\
\hline FY 2018/Q2 & Self-Assessment & Contractor & All \\
\hline FY 2018/Q3 & $\begin{array}{c}\text { Contractor Oversight } \\
\text { Assessment }\end{array}$ & Field Office & All \\
\hline
\end{tabular}

\section{STATUS OF CORRECTIVE ACTIONS}

Table 6a provides the status of outstanding and overdue emergency management corrective actions identified in response to findings assessed by oversight organizations (e.g., GAO, IG, EA, DNFSB, CDNS) external to your program.

Table 6a. Status of Outstanding and Overdue Corrective Actions.

\begin{tabular}{|c|c|c|c|}
\hline \multicolumn{1}{|c|}{ Corrective Action (Issue \#/Title) } & Status & Original Due Date & $\begin{array}{c}\text { Projected } \\
\text { Completion }\end{array}$ \\
\hline $\begin{array}{l}\text { LP-GA 2017-0080, GDE-467, "Drills and } \\
\text { Exercises" Issuance }\end{array}$ & $\begin{array}{c}\text { Updating } \\
\text { procedure }\end{array}$ & N/A & $02 / 01 / 2018$ \\
\hline
\end{tabular}

The number of closed corrective actions that have been reviewed by the Cognizant Field Element (CFE) and the total number of closed corrective actions that were reviewed and found inadequate (ineffective, incomplete, unacceptable) by the CFE are identified in Table 6b.

Table 6b. Validated Corrective Actions.

\begin{tabular}{|l|l|}
\hline Total number of closed corrective actions reviewed by the CFE & 1 \\
\hline Total number of closed corrective actions reviewed and found inadequate by the CFE & 0 \\
\hline
\end{tabular}

\section{RESOURCE REQUIREMENTS}

Table 7a provides the total number of full-/part-time Site/facility personnel required for FY 2017 and estimated for FY 2018 for contractor staff.

Table 7a. Emergency Management Personnel Full-Time Equivalents.

\begin{tabular}{|l|c|c|}
\hline Organization & FY 2017 & FY 2018 \\
\hline Battelle Energy Alliance, LLC (BEA) & 19 & 19 \\
\hline Total & 19 & 19 \\
\hline Explanation: N/A & \multicolumn{2}{|l}{} \\
\hline
\end{tabular}

INL EM is fully funded. Table $7 \mathrm{~b}$ summarizes the INL EM Program operational budget.

Table 7b. Emergency Management Operational Budget.

\begin{tabular}{|l|c|c|}
\hline Organization & FY 2017 & FY 2018 \\
\hline Battelle Energy Alliance, LLC (BEA) & $\$ 2,699,375$ & $\$ 2,885,058^{1}$ \\
\hline Explanation: ${ }^{1}$ Increase in average charge out rates & \multicolumn{2}{|l}{} \\
\hline
\end{tabular}


Table $7 \mathrm{c}$ lists equipment requirements that are not included in the operational budget.

Table 7c. Equipment Requirements.

\begin{tabular}{|l|c|c|}
\hline Item & FY 2017 & FY 2018 \\
\hline N/A & 0 & 0 \\
\hline
\end{tabular}

\section{PROGRAMMATIC ISSUES}

Over the past 18 months, INL EM staff have been in discussions regarding the implementation impacts of the new order, DOE Order 151.1D, "Comprehensive Emergency Management System," with DOE-ID counterparts. As information was released on the new order, EM provided pushback on requirements and changes found to be unreasonable or not needed. In addition, two EM staff attended several face-to-face meetings with DOE-HQ to work on key issues. Some of our efforts were successful, such as the basic elimination of the Globally Harmonized System (GHS) effort from the order and a significant lowering of requirements in the area of Threat and Hazard Identification/Risk Assessment (THIRA) requirements. If not reduced these efforts would have caused much more than a significant impact to our organization. EM was not as successful in pushback and change in other areas of the order. The INL EM manager has had many meetings with the DOE customers. In these meetings, both INL EM and Flour Idaho, LLC emergency management expressed great concerns for implementation of this order. The lack of guidance (e.g., DOE Guides) and inconsistent interpretation of the order left us in a quandary.

The main topics of concern include the following:

- Implementation

- ERO training

- Protective actions

- Notifications and communications

- Readiness assurance

- Emergency categorization and emergency classification and response

- Emergency response organization professionals

- THIRA

- Global Harmonization Issues.

Although these and other issues have been pushed to our local and national DOE representatives, the INL EM group has seen little to no relief. 


\section{PROGRAM GOALS AND ACHIEVEMENTS}

Table 9a compares actual INL EM Program achievements accomplished during FY 2017 to projected goals, milestones, and objectives.

Table 9a. INL EM Program achievements (goals, milestones, objectives, and status) for FY 2017.

\begin{tabular}{|c|c|c|c|}
\hline Fiscal Year 2017 Goal & Milestones & Objective & Status \\
\hline $\begin{array}{l}\text { Conduct annual FY } 2017 \\
\text { sitewide exercise }\end{array}$ & $\begin{array}{l}\text { Exercise final plan } \\
\text { approved - at least } \\
30 \text { days prior to exercise } \\
\text { Exercise conducted — date } \\
\text { undetermined } \\
\text { Exercise report submitted } \\
\text { - within } 45 \text { days } \\
\text { following exercise }\end{array}$ & $\begin{array}{l}\text { Successfully accomplish } \\
\text { exercise objectives and } \\
\text { submit report }\end{array}$ & $\begin{array}{l}\text { Successfully } \\
\text { accomplished exercise } \\
\text { objectives and } \\
\text { submitted report. }\end{array}$ \\
\hline $\begin{array}{l}\text { Conduct annual review of } \\
\text { EPHSs, and revise, if } \\
\text { necessary }\end{array}$ & & $\begin{array}{l}\text { Review EPHSs and revise, } \\
\text { if necessary, by end of } \\
\text { calendar year (CY) } 2017\end{array}$ & $\begin{array}{l}\text { All EPHS reviews } \\
\text { completed as } \\
\text { scheduled }\end{array}$ \\
\hline $\begin{array}{l}\text { Conduct annual review of } \\
\text { EPHAs, and revise, if } \\
\text { necessary }\end{array}$ & & $\begin{array}{l}\text { Review EPHAs and revise, } \\
\text { if necessary, by end of CY } \\
2017\end{array}$ & $\begin{array}{l}\text { All EPHA reviews } \\
\text { completed as } \\
\text { scheduled }\end{array}$ \\
\hline $\begin{array}{l}\text { Complete annual review of } \\
\text { PLN-114 and revise, if } \\
\text { necessary }\end{array}$ & & $\begin{array}{l}\text { Review PLN-114 and } \\
\text { revise, if necessary, by end } \\
\text { of FY } 2017\end{array}$ & $\begin{array}{l}\text { Reviewed PLN-114 } \\
\text { and revised }\end{array}$ \\
\hline $\begin{array}{l}\text { Conduct initial training for } \\
\text { new ERO members }\end{array}$ & $\begin{array}{l}\text { Classes conducted, as } \\
\text { needed }\end{array}$ & $\begin{array}{l}\text { Conduct initial training for } \\
\text { all new ERO members }\end{array}$ & $\begin{array}{l}\text { Completed initial } \\
\text { training for all new } \\
\text { ERO members }\end{array}$ \\
\hline $\begin{array}{l}\text { Conduct annual ERO } \\
\text { requalification training for } \\
\text { CY } 2017\end{array}$ & & $\begin{array}{l}\text { Complete annual ERO } \\
\text { requalification training for } \\
\text { CY } 2017\end{array}$ & $\begin{array}{l}\text { Complete annual ERO } \\
\text { requalification } \\
\text { training for CY } 2017\end{array}$ \\
\hline $\begin{array}{l}\text { Complete ERAP for FY } \\
2017\end{array}$ & & Complete FY 2017 ERAP & $\begin{array}{l}\text { FY } 2017 \text { ERAP } \\
\text { scheduled for } \\
\text { completion by } \\
\text { September } 30,2017\end{array}$ \\
\hline $\begin{array}{l}\text { Conduct annual facility } \\
\text { evaluated drills }\end{array}$ & & $\begin{array}{l}\text { Successfully conduct } \\
\text { facility evaluated drills }\end{array}$ & $\begin{array}{l}\text { Drills successfully } \\
\text { conducted or are } \\
\text { scheduled as per the } \\
\text { approved drill } \\
\text { schedule }\end{array}$ \\
\hline $\begin{array}{l}\text { EM Technology } \\
\text { improvement initiative }\end{array}$ & & & $\begin{array}{l}\text { Developed Five-Year } \\
\text { Strategic Equipment } \\
\text { Plan }\end{array}$ \\
\hline $\begin{array}{l}\text { EM Training program } \\
\text { initiative }\end{array}$ & & & $\begin{array}{l}\text { Updated and issued } \\
\text { training procedure }\end{array}$ \\
\hline EM Incident Command & & & Developed path \\
\hline
\end{tabular}


Table 9b. (continued).

\begin{tabular}{|l|l|l|l|}
\hline Fiscal Year 2017 Goal & Milestones & Objective & \multicolumn{1}{c|}{ Status } \\
\hline $\begin{array}{l}\text { System (ICS) } \\
\text { implementation initiative }\end{array}$ & & & $\begin{array}{l}\text { forward for } \\
\text { implementation }\end{array}$ \\
\hline
\end{tabular}

Table 9b describes the INL EM Program goals and milestones for FY 2018.

Table 9b. INL EM Program projections (goals, milestones) for FY 2018.

\begin{tabular}{|l|l|l|}
\hline \multicolumn{1}{|c|}{ Goal } & \multicolumn{1}{|c|}{ Milestones } & \multicolumn{1}{c|}{ Objective } \\
\hline $\begin{array}{l}\text { Conduct annual FY 2018 sitewide } \\
\text { exercise }\end{array}$ & $\begin{array}{l}\text { Exercise final plan approved — at } \\
\text { least 30 days prior to exercise } \\
\text { Exercise conducted — date } \\
\text { undetermined } \\
\text { Exercise report submitted — within } \\
\text { 45 days following exercise }\end{array}$ & $\begin{array}{l}\text { Successfully accomplish } \\
\text { exercise objectives and submit } \\
\text { report }\end{array}$ \\
\hline $\begin{array}{l}\text { Conduct annual review of EPHSs, } \\
\text { and revise, if necessary }\end{array}$ & & $\begin{array}{l}\text { Review EPHSs and revise, if } \\
\text { necessary, by end of CY 2018 }\end{array}$ \\
\hline $\begin{array}{l}\text { Conduct annual review of EPHAs, } \\
\text { and revise, if necessary }\end{array}$ & $\begin{array}{l}\text { Review EPHAs and revise, if } \\
\text { necessary, by end of CY 2018 }\end{array}$ \\
\hline $\begin{array}{l}\text { Complete annual review of PLN-114 } \\
\text { and revise, if necessary }\end{array}$ & $\begin{array}{l}\text { Review PLN-114 and revise, if } \\
\text { necessary, by end of FY 2018 }\end{array}$ \\
\hline $\begin{array}{l}\text { Conduct initial training for new ERO } \\
\text { members }\end{array}$ & Classes conducted, as needed & $\begin{array}{l}\text { Conduct initial training for all } \\
\text { new ERO members }\end{array}$ \\
\hline $\begin{array}{l}\text { Conduct annual ERO requalification } \\
\text { training for CY-2018 }\end{array}$ & $\begin{array}{l}\text { Complete annual ERO } \\
\text { requalification training for CY } \\
\text { 2018 }\end{array}$ \\
\hline Complete ERAP for FY 2018 & Complete FY 2018 ERAP \\
\hline $\begin{array}{l}\text { Conduct annual facility evaluated } \\
\text { drills }\end{array}$ & & $\begin{array}{l}\text { Successfully conduct facility } \\
\text { evaluated drills }\end{array}$ \\
\hline $\begin{array}{l}\text { EM Technology improvement } \\
\text { initiative }\end{array}$ & $\begin{array}{l}\text { Develop Five-Year Strategic } \\
\text { Equipment Plan }\end{array}$ \\
\hline EM Training program initiative & $\begin{array}{l}\text { Update and issue training } \\
\text { procedure }\end{array}$ \\
\hline EM ICS implementation initiative & $\begin{array}{l}\text { Continue to develop path } \\
\text { forward for implementation }\end{array}$ \\
\hline
\end{tabular}




\section{Appendix A DOE O 151.1D Implementation Schedule}

Phased implementation of DOE O 151.1D will begin immediately following receipt of the DOE guide. However, initiation of all aspects of this implementation plan will require up to five (5) years from the date the guide is provided to BEA. 
INTENTIONALLY LEFT BLANK. 


\section{Appendix B \\ Threat and Hazard Identification Risk Assessment (THIRA)}

A team of representatives from BEA, Fluor-Idaho, and DOE-ID has been established and will coordinate efforts for developing INL's THIRA. The Emergency Management Issues Special Interest Group (EMISIG), in conjunction with DOE Headquarters, has developed a standard process for sites to use in THIRA development. The team will follow this process. 